\title{
PELAYANAN KESEHATAN TERNAK DI WILAYAH DESA PENGOTAN, KECAMATAN BANGLI, KABUPATEN BANGLI
}

\author{
I.N. Suarsana ${ }^{1}$, I.M. Kardena ${ }^{2}$, dan I.P.G.Y. Arjentinia ${ }^{3}$
}

\begin{abstract}
ABSTRAK
Penyakit merupakan salah faktor penting dalam sistem produksi dan produktivitas ternak. Upaya pengendalian penyakit dapat dilakukan melalui usaha pencegahan penyakit dan atau pengobatan pada ternak yang sakit. Pelayanan kesehatan ternak sapi dan babi dilaksanakan di Desa Pengotan, Kecamatan Bangli, Kabupaten Bangli dalam program hibah KKN PPM. Tujuan kegiatan ini adalah untuk mempertahankan dan meningkatkan kesehatan ternak sapi dan babi sehingga produktivitas dan produksi ternak dapat ditingkatkan. Metode pendekatan yang digunakan adalah dengan melibatkan anggota Gapoktan Asta murti maupun secara individu yang memiliki ternak. Secara klinis ternak diamati kondisi eksterior dan wawancara dengan pemilik untuk mengetahui kondisi awal kesehatan ternak dan tindakan medicine selanjutnya. Hasil kegiatan pelayanan kesehatan ternak menunjukkan hanya 2 jenis ternak yang diberi layanan kesehatan yaitu sapi bali dan babi. Secara keseluruhan layanan kesehatan terhadap sapi bali sebanyak 303 ekor dan babi sebanyak 146 ekor. Pelayanan dilakukan di 8 dusun yang ada di desa Pengotan dengan rincian dusun Besange 108 ekor, dusun Sunting 41 ekor, Dusun Penyebeh 39 ekor, Dusun Yoh 29 ekor, Dusun delod desa 72 ekor, Dusun dajan umah 43 ekor, dan Dusun Tiying 117 ekor. Jenis layanan kesehatan yang diberikan adalah pemberian vitamin, obat cacing dan sparying ektoparasit. Disimpulkan bahwa ternak sapi dan babi di desa Pengotan dalam kondisi sehat. Intervensi dengan pemberian vitamin, obat cacing dan obat ektoparasit meningkatkan performance ternak sapi bali dan babi.
\end{abstract}

Kata kunci : sapi bali, babi, Desa Pengotan, Gapoktan Asta Murti

\begin{abstract}
Disease is an important factor in the production system and livestock productivity. Efforts to control the disease can be done through the prevention of disease and or treatment of sick livestock. Health services of cattle and pigs are carried out in Pengotan Village, Bangli District, Bangli Regency in the grant program of KKN PPM. The purpose of this activity is to maintain and improve the health of bali cattle and pigs so that the productivity and production of livestock can be improved. Approach method used is by involving members of Gapoktan Asta murti or individually who have livestock. Clinically cattle observed exterior conditions and interviews with owners to find out the initial conditions of livestock health and subsequent medicine action. The results of livestock health service activities show only 2 types of livestock are given health services namely bali cattle and pigs. Overall health services to bali cattle as many as 303 heads and 146 pigs. The service was carried out in 8 dusun in Pengotan village with details of dusun Besange 108, dusun Sunting 41, Dusun Penyebeh 39, Dusun Yoh 29, Dusun delod village 72 heads, Dusun dajan umah 43, and Dusun Tiying 117. Type of health services provided is the provision of vitamins, worm medicine and sparying of ectoparasit. It was concluded that cattle and pigs in Pengotan village are in good condition. Intervention with the provision of vitamins, worm medicines and ectoparasit drugs improves the performance of bali cattle and pigs
\end{abstract}

Keywords: bali cattle, pig, Pengotan village, Gapoktan Asta Murti

\footnotetext{
${ }^{1}$ Lab. Biokimia Veteriner Fakultas Kedokteran Hewan, Universitas Udayana, Jln. PB Sudirman, Denpasar, Bali, suarsana65@yahoo.com

${ }^{2}$ Lab Patologi Veteriner, Fakultas Kedokteran Hewan, Universitas Udayana, Jln. PB Sudirman, Denpasar, Bali

${ }^{3}$ Lab. Penyakit Dalam Veteriner, Fakultas Kedokteran Hewan, Universitas Udayana, Jln. PB Sudirman, Denpasar, Bali
} 


\section{PENDAhUluan}

Desa Pengotan merupakan salah satu dari 9 desa yang berada di wilayah Kecamatan Bangli Kabupaten Bangli. Desa Pengotan terdiri dari 8 dusun yaitu Dusun Besenga, Penyebeh, Padpadan, Yoh, Tiying Desa, Delod Umah, Dajan Umah, dan Sunting. Jarak Desa Pengotan ke pusat kota kecamatan atau Kabupaten Bangli sekitar 17 kilometer. Desa Pengotan wilahnya terbentang sekitar $9 \mathrm{~km}^{2}$, terletak di ketinggian sekitar $800 \mathrm{~m}$ dpl. Berdasarkan data terbaru yang diperoleh dari kantor kepala desa jumlah peduduk sekitar 3.793 jiwa berasal dari 1.026 KK (Anon, 2015).

Mayoritas rumah tangga di desa ini bekerja disektor pertanian, selain itu juga disektor peternakan dengan memelihara ternak sapi, babi, dan ayam. Hasil analisis monograph Desa Pengotan, Kabupaten Bangli tahun 2014 mengungkapkan bahwa populasi sapi sampai 3500 ekor, babi 4000 ekor, ayam 30.000 ekor. Populasi sapi yang besar menjadikan Desa Pengotan sebagai pemasok terbesar ternak sapi di Kabupaten Bangli. Sejumlah sapi tersebut dipeliharan dan tersebar di Gapoktan serta Simantri yang ada di Desa Pengotan. . Hal ini merupakan potensi besar dibidang pengembangan peternakan di desa Pengotan untuk meningkatkan perekonomian dan kesejahteraan. Sapi bali memiliki beberapa keunggulan dibandingkan sapi-sapi yang lain yaitu baik dalam genetik, daging, maupun dalam kemampuan hidupnya.

Mata pencaharian sebagian besar penduduk adalah dari sektor peternakan dan pertanian. Di Desa Pengotan terdapat gabungan kelompok tani (Gapoktan) yan diberi nama Asta Murti. Gapoktan Asta Murti terdiri atas 11 kelompok yaitu: (1).Kelompok Ternak Ulun Sari, (2) Kelompok ternak sapi Sari Gema, (3). Kelompok Tani Sarin Tegal, (4).KUBE FM Rare Angon II, (5). KUBE FM Eka Buana Sari, (6). KUBE FM Khamaduk, (7). KUBE FM Dana Mekar, (8). KUBE FM Sari Dana, (9).KUBE FM Sari merta, (10). KUBE FM Merta Sari, dan (11). KUBE Karya Guna

Perkembangan babi Bali masih cukup baik hal ini disebabkan babi bali mempunyai keunggulan. Babi bali memiliki keunggulan dapat beradaptasi dengan pola pemeliharaan yang tradisional yaitu dengan pemberian pakan yang seadanya (Soewandi et al., 2013). Keunggulan lain babi bali adalah kemampuannya mengkonsumsi limbah dapur. Menurut Suyadnya (1987), masyarakat bali seringkali menggunakan ternak babi sebagai simpanan ataua tabungan yang kemudian azim disebut sebagai "tatagan banyu". Selain itu, cita rasa daging babi bali lebih empuk, lebih enak dibandingan dengan daging babi impor.

Lebih dari 98\% sapi di Indonesia termasuk di Bali dikelola oleh peternak berskala kecil dan tersebar diseluruh pelosok pedesaan skala kepemilikan 2-3 ekor per peternak (Muladno, 2012). Lebih lanjut di jelaskan untuk meningkatkan kualitas dan kuantitas sapi milik peternak atau kelompok peternak maka penerapan teknologi bidang pakan, reproduksi dan kesehatan hewan merupakan suatu keniscayaan guna meningkatkan pendapatan dan kesejahteraan peternak berskala kecil.

Upaya pengendalian penyakit dapat dilakukan melalui usaha pencegahan penyakit dan atau pengobatan pada ternak yang sakit. Oleh karena itu tindakan manajemen pemeliharaan dan kesehatan yang baik sangat diperlukan untuk keberlangsungan produksi peternakan. Tujuan kegiatan ini adalah untuk mempertahankan dan meningkatkan kesehatan ternak sapi dan babi sehingga produktivitas dan produksi ternak dapat ditingkatkan

\section{METODE PELAKSANAAN}

Metode yang digunakan dalam memecahkan masalah pelayanan kesehatan ternak di Desa Pengotan adalah dengan pendekatan pemberdayaan dan pelayanan kesehatan ternak. Pemberdayaan peternak dilakukan secara individu di lapangan, dan secara kelompok melalui penyuluhan terstruktur. Pendekatan metode dengan penyuluhan dan intervensi (Suarsana et al., 2016), yaitu 1. Penyuluhan ini ditekankan pada transper pengetahuan tentang kesehatan ternak sapi bali secara umum meliputi 


\section{N. Suarsana, I. M. Kardena, I. P. G. Y. Arjentinia}

penyakit, pengobatan, pencegahan dan cara pemeliharaan. 2. Intervensi melalui pelayanan kesehatan hewan dengan pemberian vitamin, obat cacing dan spraying anti-ektoparasit.

\section{HASIL DAN PEMBAHASAN}

Kegiatan pelayanan kesahatan ini merupakan kegiatan lanjutan dari penyuluhan manajemen pemeliharaan dan kesehatan ternak. Kegiatan pelayanan dalam bentuk kuratif dilaksanakan selama KKN berlangsung. Metode yang digunakan dengan pendekatan individu dan pendekatan gapoktan. Penyuluhan tentang kesehatan langsung dilakukan pada pemilik ternak di tempat atau dikandang tempat ternak diberikan layanan kesehatan. Metode pendekatan individu ini dirasa lebih efektif dalam menanamkan aspek-aspek kesehatan dan aspek pemeliharaan ternak. Namun memerlukan waktu yang lebih lama dan membutuhkan kesabaran. Mahasiswa KKN telah dilengkapi dengan peralatan medis secukupnya dan obat-obatan seperti vitamin, antibiotik, obat cacing dan spraying anti-ektoparasit. Dalam melakukan pelayanan mahasiswa didampingi oleh tenaga medis kesehatan hewan di Kecamatan Bangli yang mewilayahi desa Pengotan.
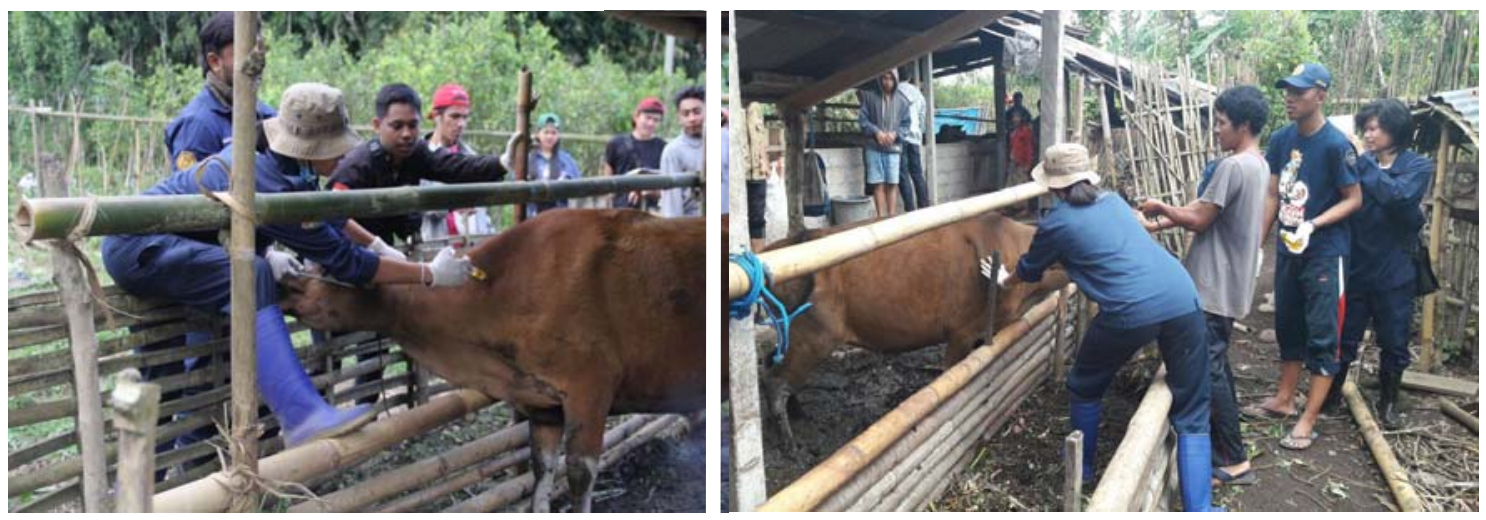

Gambar 1. Mahasiswa KKN sedang melakukan pelayanan kesehatan pada ternak sapi bali dan pemilik sapi ikut aktif berpartisipasi dalam mensukseskan pelayanan kesehatan hewan.

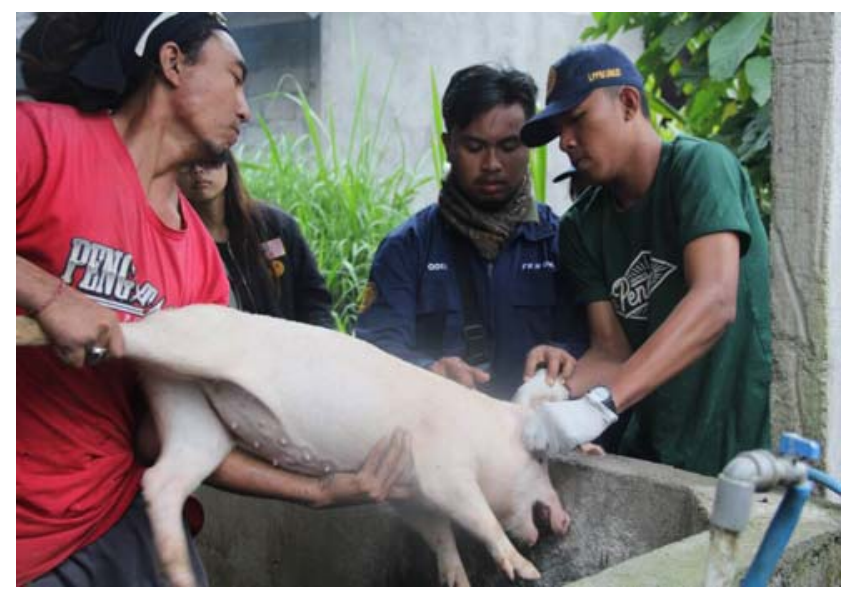

Gambar 2. Mahasiswa KKN sedang melakukan pelayanan kesehatan pada ternak babi. 
Selama pelaksanaan kegiatan pelayanan kesehatan ternak, mahasiswa KKN tidak saja memberi pelayanan kesehatan pada sapi bali tetapi juga ternak babi. Berdasarkan hasil pelayanan kesehatan ternak yang dilakukan, telah berhasil memberi pelayanan pada ternak sapi dengan total 303 dan babi sebanyak 146 ekor. Pelayanan dilakukan di 8 dusun yang ada di desa Pengotan dengan rincian dusun Besange 108 ekor, dusun Sunting 41 ekor, Dusun Penyebeh 39 ekor, Dusun Yoh 29 ekor, Dusun delod desa 72 ekor, Dusun dajan umah 43 ekor, dan Dusun Tiying 117 ekor. (Gambar $3)$.

PELAYANAN KESEHATAN TERNAK

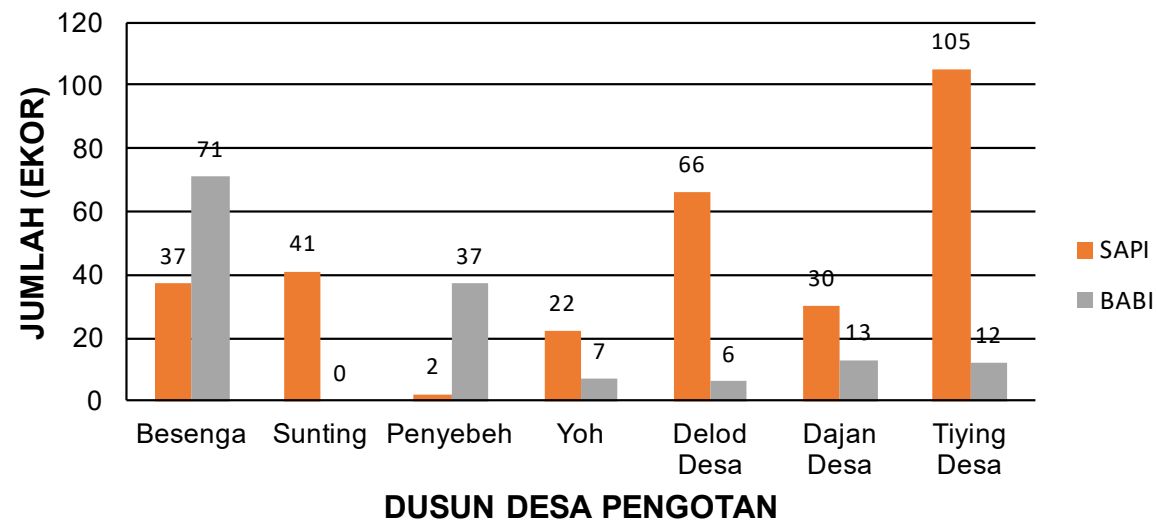

Gambar 3. Pelayanan kesehatan ternak di 8 Dusun Desa Pengotan selama pelaksanaan Hibah KKN PPM

Jenis layahan kesehatan yang diberikan adalah pemberian vitamin, obat cacing dan spyarying ektoparasit. Secara keseluruhan layanan kesehatan terhadap sapi bali sebanyak 303 ekor dan babi sebanyak 146 ekor (Gambar 4).

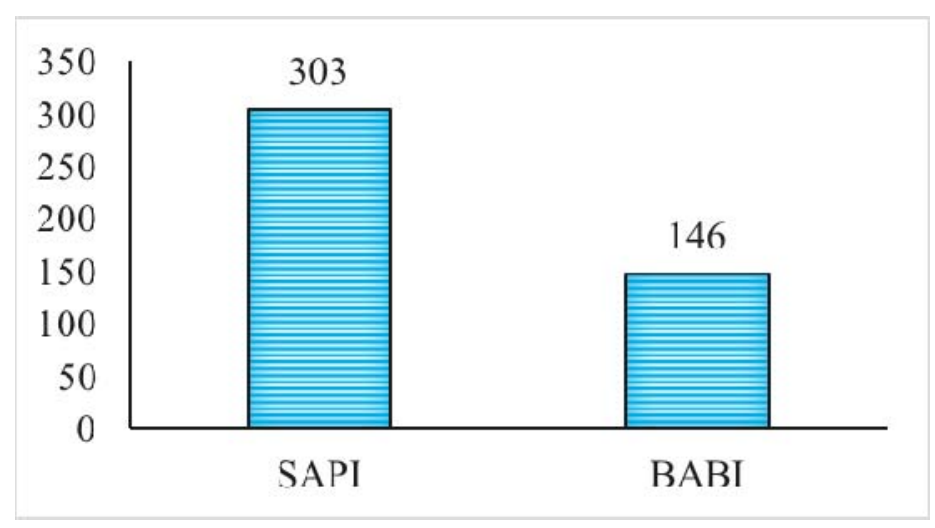

Gambar 4. Pelayanan kesehatan ternak sapi bali dan babi di Desa Pengotan selama pelaksanaan Hibah KKN PPM

Berdasarkan UU No 18, tahun 2009 (Anon, 2009) tentang Peternakan dan Kesehatan Hewan, yang dimaksud dengan penyakit hewan adalah gangguan kesehatan pada hewan yang antara lain, disebabkan oleh keracunan, infestasi parasit, dan infeksi mikroorganisme patogen seperti virus, bakteri, cendawan, dan ricketsia. Pada pelaksanaan kegiatan pelayanan kesehatan hewan di Desa Pengotan tidak ditemukan baik penyakit hewan zoonosis maupun penyakit hewan strategis yaitu 
penyakit hewan yang dapat menimbulkan kerugian ekonomi, keresahan masyarakat, dan/atau kematian hewan.

Pencegahan penyakit hewan sebagaimana dimaksud dalam undang-undang kesehatan hewan, dapat dilakukan dengan tindakan pengebalan, pengoptimalan kebugaran hewan, dan biosecurity (Anon, 2014). Pencdegahan yang dimaksud pada pelaksanaan KKN PPM ini adalah tindakan kuratif dilaksanakan melalui pemberian vitamin, obat cacing dan peningkatan status gizi dan ksehatan ternak.

Vitamin adalah sekelompok senyawa organik yang penting untuk fungsi fisiologis normal tetapi tidak disintesis secara endogen oleh tubuh dan oleh karena itu harus mendapat asupan dalam jumlah kecil dari pakan. Vitamin B terdiri dari kelompok vitamin yang larut dalam air dan melakukan peran penting yang saling terkait dalam fungsi selular, bertindak sebagai co-enzim dalam proses reaksi katabolik dan anabolik untuk menghasilkan energi (Kennedy, 2016). Termasuk vitamin B, yaitu thiamine (B1), riboflavin (B2), niacin (B3), pantothenic acid (B5), vitamin B6, folate (B9) and vitamin B12. Pada pelayanan ternak sapi bali dan babi diberi vitamin kompleks dengan harapan proses metabolisme di dalam tubuh meningkat dan reaksi kimia katabolik dan anabolik berjalan dengan baik dan seimbang.

\section{KESIMPULAN DAN SARAN}

Berdasarkan hasil pelayanan kesehatan ternak di wilayah desa Pengotan, dapat disimpulkan sebagai berikut:

1. Secara umum ternak sapi dan babi di wilayah desa Pengotan dalam kondisi sehat.

2. Berdasarkan intervensi kesehatan telah berhasil diberi layanan kesehatan terhadap 303 ekor sapi bali dan 146 ekor babi.

Intervensi kesehatan terhadap hewan sejenis perlu berkelanjutan dan jangkauannya lebih diperluas agar semua kelompok peternak diwilayah desa Pengotan terjangkau dan ternaknya dapat diberi pelayanan kesehatan.

\section{UCAPAN TERIMA KASIH}

Ucapan terimakasih disampaikan kepada Direktorat Riset dan Pengabdian Kepada Masyarakat

Direktorat Riset dan Pengabdian Kepada Masyarakat Direktorat Jendral Penguatan Riset dan Pengembangan Kementerian Riset, Teknologi dan Pendidikan Tinggi. Sesuai dengan kontrak Pengabdian Kepada Masyarakat No:416.30/UN14.4.A/ PM/2017, Tanggal 30 Maret 2017

\section{DAFTAR PUSTAKA}

Anonimos. 2009. Undang-Undang Republik Indonesia Nomor 18 Tahun 2009 Tentang Peternakan Dan Kesehatan Hewan. Menteri Hukum Dan Hak Asasi Manusia Republik Indonesia. Jakarta.

Anonimous, 2015. Peta Profil Desa Pengotan Tahun 2014. Desa Pengotan, Kecamatan Bangli, Kabupaten Bangli.

Anonimous. 2014. Peraturan Pemerintah Republik Indonesia Nomor 47 Tahun 2014 Tentang Pengendalian Dan Penanggulangan Penyakit Hewan. Menteri Hukum Dan Hak Asasi Manusia Republik Indonesia. Jakarta.

Kennedy DO. 2016. B Vitamins and the Brain: Mechanisms, Dose and Efficacy. A Review. Nutrients 8(68); doi:10.3390/nu8020068. 29 pages.

Muladno. 2012. Aplikasi Teknologi Perbibitan untu Peningkatan Produksi Bakalan dan Kualitas daging Sapi Nasional. Di dalam proseding Semina Nasional Peningkatan Produksi dan Kualitas Daging Spai Bali Nasional. Bali, 14 Septmebr 2012. Pusat Kajian Sapi Bali Universitas Udayana. Halaman 1-15

VOLUME 17 NOMOR 1, JANUARI 2018 | 23 
Soewandi, B.D.P, Sumadi, dan Hartatik T. 2013. Estimasi Output Babi Di Kabupaten Tabanan Provinsi Bali. Buletin Peternakan Vol. 37(3): 165-172.

Suarsana N., Suatha, IK., Sampurna P, ardena IM, Suardana IW., dan Utama IH. 2016. Pelayanan kesehatan sapi bali di wilayah lingkar kampus Universitas Udayana Bukit Jimbaran Kecamatan Kuta Selatan, Kabupaten Badung. Udayana Mengabdi Vol 15(2):59-66

Suyadnya, I. P. 1987. Peningkatan produksi anak babi Bali melalui superovulasi dan pemacuan. Disertasi. Fakultas Pasca Sarjana Institut Pertanian Bogor. Bogor 